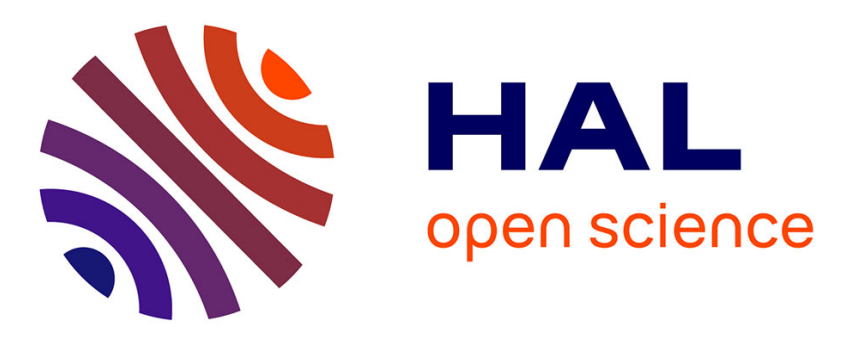

\title{
Induction of the HSP70 gene promoter by various anticancer drugs
}

\author{
Selim Ait-Aissa, Jean-Marc Porcher, C. Kretz-Remy, G. Velarde, \\ André-Patrick Arrigo, Claude Lambre
}

\section{- To cite this version:}

Selim Ait-Aissa, Jean-Marc Porcher, C. Kretz-Remy, G. Velarde, André-Patrick Arrigo, et al.. Induction of the HSP70 gene promoter by various anticancer drugs. Toxicology in Vitro, 1999, 13 (4-5), pp.651-655. 10.1016/S0887-2333(99)00032-6 . ineris-00961849

HAL Id: ineris-00961849

https://hal-ineris.archives-ouvertes.fr/ineris-00961849

Submitted on 20 Mar 2014

HAL is a multi-disciplinary open access archive for the deposit and dissemination of scientific research documents, whether they are published or not. The documents may come from teaching and research institutions in France or abroad, or from public or private research centers.
L'archive ouverte pluridisciplinaire HAL, est destinée au dépôt et à la diffusion de documents scientifiques de niveau recherche, publiés ou non, émanant des établissements d'enseignement et de recherche français ou étrangers, des laboratoires publics ou privés. 


\title{
INDUCTION OF THE HSP70 GENE PROMOTER BY VARIOUS
}

\section{ANTICANCER DRUGS}

\author{
S. AÏT-AÏSSA ${ }^{1}$, J-M. PORCHER ${ }^{1}{ }^{*}$, C. KRETZ-REMY ${ }^{2}$, G. VELARDE ${ }^{1}$, A-P. ARRIGO ${ }^{2}$ \\ and C. LAMBRE ${ }^{1}$ \\ 'Laboratoire de Biochimie et Toxicologie in vitro, Institut National de l'Environnement Industriel \\ et des Risques (INERIS), F-60550 Verneuil-en-Halatte, France and ${ }^{2}$ Laboratoire du Stress \\ Cellulaire, Centre de Génétique Moléculaire et Cellulaire, CNRS-UMR 5534, Université Claude \\ Bernard Lyon-I, F-69622 Villeurbanne, France. \\ *corresponding author: e-mail: jean-marc.porcher@ineris.fr, Tel:(33)344556584, \\ fax:(33)344556605.
}

\begin{abstract}
HeLa cells containing the chloramphenicol acetyl transferase (CAT) gene under the control of the $h s p 70$ promoter have been exposed in vitro to various anticancer drugs. Cisplatin induced CAT production with a dose-effect relationship at a non-cytotoxic dose, whereas no induction was detected with carboplatin. Etoposid induced a significant response at a cytotoxic concentration. The limited positive response with doxorubicin, daunomycin and mitoxantrone was not statistically significant. These chemicals are known to produce reactive oxygen species and induce apoptosis. No induction of the $h s p 70$ promoter could be detected with the other cytostatic compounds that have been tested such as base analogs (5-fluorouracil, cytosine arabinoside 3'-MP), inhibitors of DNA synthesis (amethopterin, aminopterin), antimitotics (vinblastine, colchicine), and alkylating (streptozotocine, carboplatin, melphalan) or intercalating agents (bleomycin). In addition, the role of the transcription inhibitory activity of doxorubicin in this model is evidenced and the consequent question of the suitability of the reporter gene system is discussed. Our results suggest that specific genotoxic compounds are not able to induce the hsp70 promoter, and are in agreement with the concept that stimulation of HSP70 synthesis occurs through a biochemical process involving proteotoxicity.
\end{abstract}

Keywords: $h s p 70$ promoter; anticancer drug; HeLa cells.

\section{INTRODUCTION}


A wide range of physical, chemical and biological agents are known to induce a set of cellular stress proteins, the heat-shock proteins (HSP). This occurs through a mechanism of toxicity involving the generation of denatured proteins by the stressors (Hightower, 1991) and resulting in the binding of a heat shock factor (HSF) to specific DNA sequences called heat shock elements. Among the different stress proteins, the HSP70 family is the most abundant and conserved. It has frequently been proposed as a biomarker of cellular toxicity (Fishbach et al., 1993; Ryan and Hightower, 1996).

Anticancer drugs represent a growing threat in environmental health as reported by occupational exposure monitoring (Bos et al., 1998) and sewage water contamination by hospital effluents studies (Kümmerer and Helmers, 1997). Many studies showed expression of stress proteins in response to such agents (Bielka et al., 1994; Ciocca et al., 1993; Matsumoto et al., 1998). While in most cases the small HSPs (HSP27) rather than HSP70 are induced in response to these compounds, high intracellular levels of both HSPs induced by heat shock or constitutively overexpressed, are closely related to cellular resistance development against these drugs (Ciocca et al., 1993; Garrido et al., 1997; Roigas et al., 1998), hence posing problems in cancer therapy. In this study, we apprehended the use of an established transformed HeLa cell line, obtained by transfection with a plasmid construct carrying the human $h s p 70$ promoter linked to the chloramphenicol acetyl transferase (CAT) gene (Kretz-Remy and Arrigo, 1994), as an in vitro toxicity test to screen various molecules widely used in cancer chemotherapy. The relationship between induction and the mechanism of toxic action of the substances is discussed.

\section{Materials ANd Methods}

Chemicals. All chemicals were from Sigma (France) except carboplatin (Aldrich, France) and bleomycin sulfate (R. Bellon, Rhône Poulenc, France). 
Cell cultures. Transformed HeLa cells were routinely cultured at $37^{\circ} \mathrm{C}$ in complete DMEM supplemented with $10 \%$ heat inactivated foetal bovine serum (Gibco, France) and 1\% antibiotics in a humidified atmosphere containing $5 \% \mathrm{CO}_{2}$.

Induction of the hsp70 promoter. For the induction experiment, cells were seeded onto 24 -well plates (Costar) in $1 \mathrm{ml} /$ well of complete prewarmed medium and allowed to grow for 3 or 4 days until they reached $80 \%$ confluency. At this stage, various dilutions of each toxicant, made in the solvent (DMSO or saline), were added to the culture medium, $24 \mathrm{hr}$ after the last medium change. Cells were exposed for $16 \mathrm{hr}$ at $37^{\circ} \mathrm{C}$ in the presence of serum. Control wells received the same concentration of solvent alone (never exceeding $0.5 \%$ ). At the end of exposure, cells were washed twice with phosphate buffer saline, lysed and total cellular proteins were analysed using a CAT ELISA kit (Boehringer) according to the manufacturer's instructions. In each experiment, heat treatment $\left(43^{\circ} \mathrm{C}, 1 \mathrm{hr}\right)$, followed by a $24 \mathrm{hr}$ recovery period, was used as a positive control. Results are expressed as the ratio between the amount of CAT detected and the total cellular protein content assessed by an adaptation of the Lowry's method (BioRad DC Protein Assay kit). Background level in control cultures varied from 0 to $20 \mathrm{pgCAT} / \mathrm{mg}$ protein, corresponding to the range of sensitivity of the assay.

MTT assay. Cytotoxic concentrations were determined by the MTT (3-(4,5-dimethylthiazol-2-yl)2,5-diphenyltetrazolium bromide) reduction test. Cells were grown in 96-well microtiter plates until subconfluence and then exposed to toxicants as describe above. After chemical exposure, the monolayers were washed and incubated with $100 \mu 1$ of $0.5 \mathrm{mg} / \mathrm{ml}$ MTT dissolved in RPMI medium for $3 \mathrm{hr}$ at $37^{\circ} \mathrm{C}, 5 \% \mathrm{CO}_{2}$. MTT was removed and the formazen salt was solubilized, with mixing, in $100 \mu 1$ of isopropanol. Plates were read at $570 \mathrm{~nm}$ on a microtiter reader (BioTek Instruments). 


\section{RESULTS}

\section{Induction of the hsp70 promoter}

In order to set the concentrations to be tested in hsp induction experiments, cytotoxicity of the substances was evaluated in preliminary experiments by using the MTT reduction test. Since the test is carried out on subconfluent cells, cytotoxicity can be the reflect of either growth inhibition or direct cell killing or both. For the HSP experiments, serial dilutions were made including cytotoxic and non cytotoxic concentrations determined by the MTT test. The effect of these concentrations on cell viability (cytotoxicity) was further confirmed by a total protein assay performed at the end of the HSP induction experiments.

The tested toxicants showed different effects on the inducibility of the $h s p 70$ promoter (table 1 ). Cisplatin induced the promoter significantly $(\mathrm{p}<0.05)$ at a concentration $(10 \mu \mathrm{M})$ which had no significant effect on the cellular viability as measured by the total protein content and MTT assay (figure 1). Etoposid induced a significant response $(\mathrm{p}<0.05)$ at a cytotoxic concentration $(400 \mu \mathrm{M})$. A limited positive response was observed with doxorubicin, daunomycin and mitoxantrone but this appeared non statistically significant. No induction of CAT production was detected after exposure to 5-fluorouracil, cytosine arabinoside, amethopterin, aminopterin, colchicine, streptozotocine, bleomycin, carboplatin, melphalan and vinblastine. The preliminary MTT tests revealed that the first five compounds were the most cytotoxic, achieving $100 \%$ cell death at the highest concentrations tested (data not shown). Such a cytotoxicity was never obtained with the other substances at the tested concentrations (up to $10 \mathrm{mM}$ for some toxicants).

\section{Case of inhibitors of transcription}

In order to test wether protein synthesis inhibition by some toxicants could mask the detection of CAT production, cells were exposed to a heat shock $\left(43^{\circ} \mathrm{C}\right.$ for $\left.1 \mathrm{hr}\right)$ in the presence of various concentrations of doxorubicine (known as a transcription inhibitor) or streptozotocin (alkylating agent, not suspected to inhibit specifically gene expression). Lysis of cells occurred five hours after the heat shock to minimise the toxic effect of the substances. The results (figure 2) showed 
an inhibition of CAT production by doxorubicin while streptozotocine seemed to have no effect on $h s p 70$ promoter expression after heat shock. Hence, we supposed that the weakness of the observed induction with toxicants like doxorubicin, daunomycin or mitoxantrone (table 1), could be explained by an inhibitory effect on gene transcription by these toxicants. Supplementary experiments (figure 3) including recovery periods of 6 and 24 hours after the exposure time showed a stronger CAT production by doxorubicin and thus confirmed our hypothesis.

\section{DISCUSSION}

Only a few data are available concerning HSP70 induction by cytostatics in comparison to HSP25, which seems to play a major role in cellular response to such drugs. For instance, bleomycin has been previously shown to induce the $h s p 70$ promoter up to twice the control in hsp70- $\beta$-galactosidase transfected fibroblasts (Moseley et al., 1989) whereas streptozotocine did not induce any HSP synthesis in murine splenocytes in vitro (Albers et al., 1996). Bielka et al. (1994) showed that HSP25, but not HSP70, was induced by cisplatin, doxorubicin, daunomycin, cytosine arabinoside and colchicine at concentrations with $100 \%$ cytostatic effect on Ehrlich ascites carcinoma cells. Aminopterin, 5-fluorouracil and amethopterin did not induce either stress protein synthesis. In contrast, 5-fluorouracil, adriamycin (doxorubicin) and cisplatin enhanced the expression of the Drosophila hsp 70 promoter stimulated by heat shock in prostate carcinoma cells (Roigas et al., 1998). Cisplatin also stimulated HSP70 synthesis in human glioblastoma cells (Matsumoto et al., 1998) whereas in HeLa cells it provoked the migration of the protein to the nucleus without any enhancement of its synthesis (Melendez-Zajgla et al., 1996).

To some extent, our results are correlated with these observations. Among the fifteen anticancer drugs that we have tested, only cisplatin, doxorubicin, daunomycin, mitoxantrone and etoposid were able to induce an activation of the $h s p 70$ promoter (table 1, figure 1). Interestingly, MTT assays revealed that these compounds were the most cytotoxic after a 16 hour exposure (data not shown). In addition to their genotoxic effect by producing DNA damage, such as DNA adducts or 
DNA intra- and interstrand crosslinks, these compounds have various direct biochemical effects like oxidative action, interaction with cellular proteins or apoptosis induction (Calabresi and Chabner, 1990; Chu, 1994; Sacchi and Schiaffonati, 1996).

None of the other substances that we have tested in this study neither induced the $h s p 70$ promoter (table 1) nor appeared to be strongly cytotoxic (data not shown) in our experiments. Cytosine arabinoside and 5-fluorouracil (base analogs) or amethopterin and aminopterin (inhibitors of DNA synthesis by inhibition of dihydrofolate reductase) act essentially as cytostatic agents. Vinblastine and colchicine act as antimitotic agents by interacting with the microtubule system. Streptozotocine, carboplatin and melphalan are alkylating agents, similarly to the intercalating agent bleomycin, that have a physical action on DNA. Our negative result with bleomycin is not in agreement with a previous observation (Moseley et al., 1989). It looks as if substances which exert specific effects, mostly at the DNA level, and which do not interact broadly with cellular proteins, are not able to induce $h s p 70$ expression.

Our findings suggest that, in our cellular model, the observed inductions of the $h s p 70$ promoter are rather due to a cytotoxic action resulting either in protein denaturation and HSF activation or apoptosis, than to a cytostatic effect. This is in agreement with the concept that HSP70 is a marker of proteotoxicity (Hightower, 1991) rather than genotoxicity.

A further important point to discuss concerns our experimental conditions. Cell lysis occurred at the end of the $16 \mathrm{hr}$ exposure period. This time is theoretically sufficient to observe a stress protein synthesis after a cellular aggression if the gene expression machinery is not inhibited. The inhibitory action on DNA transcription by doxorubicin but not streptozotocine (figure 2), suggests that the poor induction observed in response to doxorubicin, daunomycin and mitoxantrone might have been strongly attenuated by their inhibitory action on gene expression. This effect is reversible since a significant CAT production was detected 6-hr after exposure to doxorubicin (figure 3) at concentrations where heat shock-induced CAT production is inhibited (figure 2). These observations showed that an assay based on the synthesis of marker protein is not quite 
adapted to detecting these types of effect. Thus, examination of toxicant effect on heat shock induced CAT production would be a suitable control test to detect false negatives in the case of gene expression inhibitors.

Acknowledgements - This work was supported by a doctoral fellowship from the Agence de l'Environnement et de la Maîtrise de l'Energie (to S.A.) and by the Association pour la Recherche sur le Cancer (9186), the Ligue contre le Cancer and the region Rhône-Alpes (to A.-P.A).

\section{REFERENCES}

Albers R., Van der Pijl A., Bol M., Seinen W. and Pieters R. (1996) Stress proteins (HSP) and chemical-induced autoimmunity. Toxicology and Applied Pharmacology 140, 70-76.

Bielka H., Hoinkis G., Oesterreich S., Stahl J. and Benndorf R. (1994) Induction of the small stress protein, hsp25, in Ehrlich ascites carcinoma cells by anticancer drugs. FEBS Letters $343,165-167$.

Bos R.P., Weissenberger B.F.J. and Anzion R.B.M. (1998) $\alpha$-fluoro- $\beta$-alanine in urine of workers occupationally exposed to 5-fluorouracil in a 5-fluorouracil-producing factory. Biomarkers 3, 81-87.

Calabresi P. and Chabner B.A. (1990) Chemotherapy of neoplastic diseases. In A. Goodman Gilman, T. W. Rall, A. S. Nies and P. Taylor (eds.), The pharmacological basis of therapeutics 8th Ed. Pergamon Press, pp. 1202-1263.

Chu G. (1994) Cellular response to cisplatin. The roles of DNA-binding proteins and DNA repair. The Journal of Biological Chemistry 269, 787-790.

Ciocca D.R., Oesterreich S., Chamness G.C., McGuire W.L. and Fuqua S.A.W. (1993) Biological and clinical implications of heat shock protein 27000 (Hsp27): a review. Journal of the National Cancer Institute 85, 1558-1570.

Fishbach M., Sabbioni E. and Bromley P. (1993) Induction of the human growth hormone gene placed under human hsp 70 promoter control in mouse cells: a quantitative indicator of metal toxicity. Cell Biology and Toxicology 9, 177-188. 
Garrido C., Ottavi P., Fromentin A., Hammann A., Arrigo A.-P., Chauffert B. and Mehlen P. (1997) HSP27 as a mediator of confluence-dependent resistence to cell death induced by anticancer drugs. Cancer Research 57, 2661-2667.

Hightower L.E. (1991) Heat shock, stress proteins, chaperones, and proteotoxicity. Cell 66, 191197.

Kretz-Remy C. and Arrigo A.-P. (1994) The kinetics of HIV-1 long terminal repeat transcriptional activation resemble those of hsp70 promoter in heat-shock treated HeLa cells. FEBS Letters 351, 191-196.

Kümmerer K. and Helmers, E. (1997) Hospital effluents as a source for platinum in the environment. The Science of the Total Environment 193, 179-184.

Matsumoto H., Hayashi S., Shioura H., Ohtsubo T., Kitai R., Ohnishi K., Hayashi N., Ohnishi T. and Kano E. (1998) Suppression of heat-induced HSF activation by cDDP in human glioblastoma cells. International Journal of Radiation Oncology in Biology and Physics 41, 915-920.

Melendez-Zajgla J., Garcia C. and Maldonaldo V. (1996) Subcellular redistribution of HSP72 protein during cisplatin-induced apoptosis in Hela cells. Biochemistry and Molecular Biology International 40, 253-261.

Moseley P.L., York S.J. and York J. (1989) Bleomycin induces the hsp 70 heat shock promoter in cultured cells. American Journal of Respiratory Cell and Molecular Biology 1, 89-93.

Roigas J., Wallen E.S., Loening S.A. and Moseley P.L. (1998) Effects of combined treatment of chemotherapeutics and hyperthermia on survival and the regulation of heat shock poteins in Dunning R3327 prostate carcinoma cells. The Prostate 34, 195-202.

Ryan J.A. and Hightower L.E. (1996) Stress proteins as molecular biomarkers for environmental toxicology. In U. Feige, R. I. Morimoto, I. Yahara and B. Polla (eds.), Stress-Inducible Cellular Responses, Birkhäuser Verlag Basel/Switzerland, pp. 411-424. 
Sacchi C.M. and Schiaffonati L. (1996) The effects of etoposide (VP-16) on mouse L fibroblasts: modulation of stress response, growth and apoptosis genes. Anticancer Research 16, $3659-3664$

Table 1. Summary of $h s p 70$ promoter induction in HeLa cells after a 16 hour exposure to anticancer drugs.

\begin{tabular}{lcccc}
\hline Toxicants & $\begin{array}{c}\text { Maximal induction } \\
\left(\mathrm{pgCAT}^{\mathrm{m}} \mathrm{mg}_{\text {protein }}{ }^{a}\right)\end{array}$ & $\begin{array}{c}\text { Concentration } \\
(\mu \mathrm{M})\end{array}$ & $\begin{array}{c}\text { Total protein } \\
(\% \text { of control })\end{array}$ & $\mathrm{n}^{b}$ \\
\hline cisplatin & $359 \pm 55^{*}$ & 40 & $67 \pm 2$ & 3 \\
etoposid & $91 \pm 1^{*}$ & 400 & $83 \pm 3$ & 3 \\
doxorubicin & $44 \pm 34$ & 1 & $77 \pm 2$ & 2 \\
daunorubicin & $39 \pm 10$ & 1 & $66 \pm 6$ & 2 \\
mitoxantrone & $185 \pm 107$ & 2.5 & $80 \pm 5$ & 2 \\
carboplatin & $\mathrm{nd}^{c}$ & $0.1-400^{d}$ & $74 \pm 15^{e}$ & 3 \\
bleomycin & $\mathrm{nd}$ & $10^{-9}-10^{-1}(\mathrm{mg} / \mathrm{ml})$ & $87 \pm 6$ & 3 \\
melphalan & $\mathrm{nd}$ & $0.1-1000$ & $76 \pm 7$ & 2 \\
vinblastine & $\mathrm{nd}$ & $0.001-1$ & $47 \pm 1$ & 2 \\
colchicine & $\mathrm{nd}$ & $0.001-10$ & $54 \pm 1$ & 2 \\
amethopterin & $\mathrm{nd}$ & $0.001-10$ & $82 \pm 5$ & 2 \\
aminopterin & $\mathrm{nd}$ & $0.001-25$ & $87 \pm 3$ & 2 \\
cytarabine & $\mathrm{nd}$ & $0.01-100$ & $88 \pm 4$ & 2 \\
5-fluorouracil & nd & $50-3700$ & $79 \pm 10$ & 3 \\
streptozotocine & nd & $0.01-5000$ & $85 \pm 12$ & 2 \\
\hline
\end{tabular}

*significantly different from untreated control ( $\mathrm{p}<0.05$, Dunnetts' test). $a$ : mean values \pm S.E.M. $b$ : $\mathrm{n}=$ number of independent experiments made in triplicate. From carboplatin to streptozotocine: $c$ : no induction detected (values $<20 \mathrm{pgCAT} / \mathrm{mg}$ protein); $d$ : range of the tested concentrations; $e$ : total protein content at the highest concentration. The total protein content in heat treated cultures was not significantly different from untreated control.

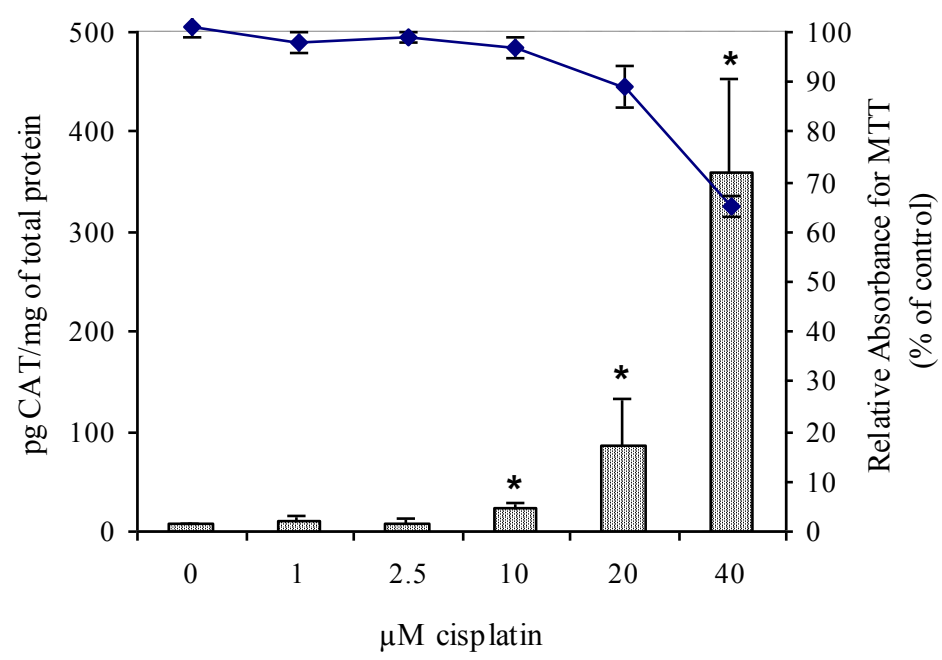


Figure1. Induction of the hsp70 promoter and survival of HeLa cells after exposure to cisplatin for 16 hours.

* significantly different from control cultures ( $\mathrm{p}<0.05$, Dunnetts' test). Values are means of three independent experiments made in triplicate. Bars: pg CAT/mg of total protein, line: MTT results.
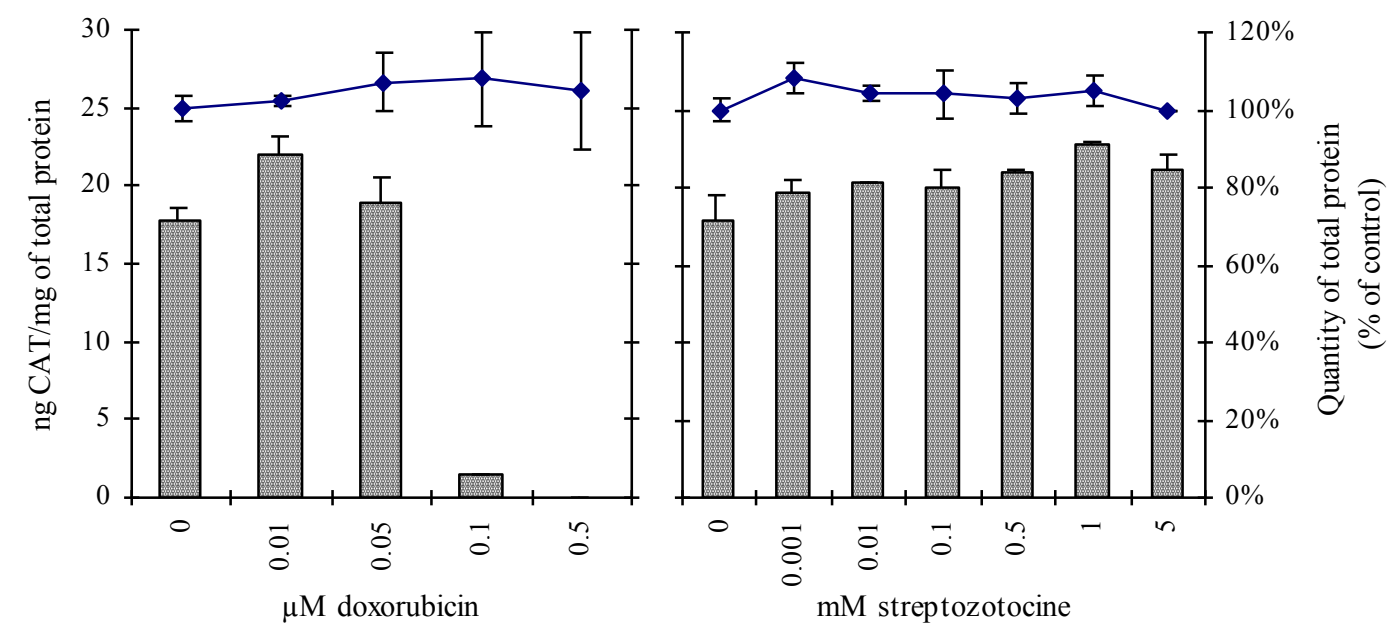

Figure 2. Effect of doxorubicin and streptozotocine on $h s p 70$ promoter activation by heat shock. HeLa cells were submitted to a sublethal heat shock $\left(43^{\circ} \mathrm{C}, 1 \mathrm{hr}\right)$ followed by a 5 hour incubation at $37^{\circ} \mathrm{C}$ in presence or not to various concentrations of doxorubicin and streptozotocine. Results are representative of two identical experiments made in triplicate. The total protein content in heat treated cultures was not significantly different from untreated control. Bras: ng CAT/mg total protein; lines: total protein ( $\%$ of heat treated control).

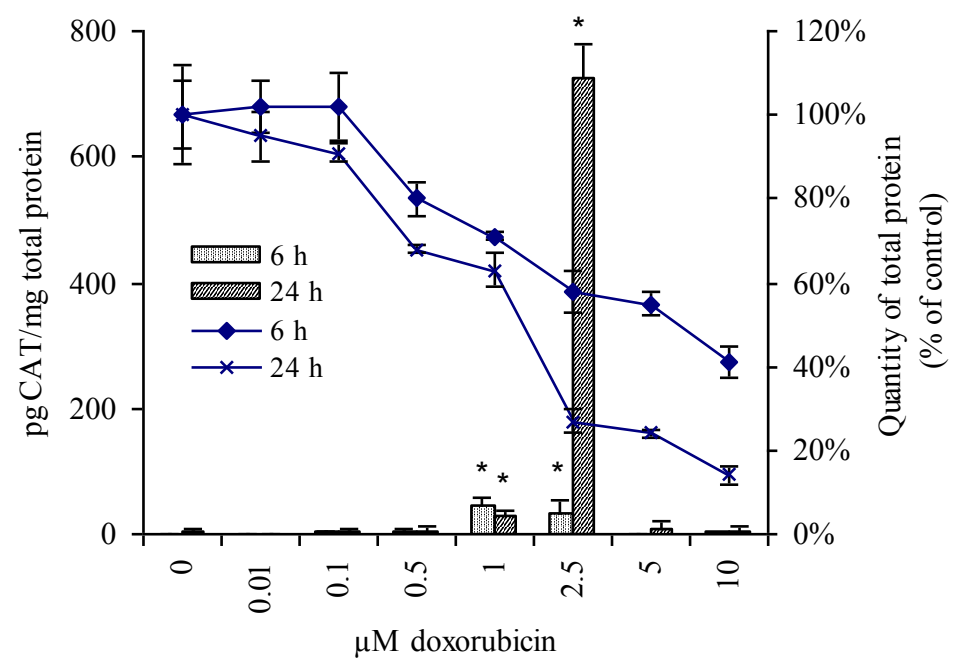

Figure 3. Induction of the hsp70 promoter by doxorubicin, 6 and 24 hours after a 16 hour exposure.

* significantly different from control cultures ( $\mathrm{p}<0.05$, Dunnetts' test). Values are representative of two independent experiments made in triplicate. Bars: pg CAT/mg of total protein, lines: quantity of total protein (\% of control). 